\title{
Leaf Area and Its Relationship with Leaf Descriptors Elements in Liquidambar styraciflua $\mathrm{L}$.
}

\author{
Daniela Sabina POŞTA ${ }^{1}$, Florin SALA ${ }^{2 *}$ \\ ${ }^{1}$ Arboriculture and Landscape Architecture, Banat University of Agricultural Sciences and Veterinary \\ Medicine "King Michael I of Romania" Timisoara, Romania \\ ${ }^{2}$ Soil Science and Plant Nutrition, Banat University of Agricultural Sciences and Veterinary Medicine \\ „King Michael I of Romania” Timisoara, Romania \\ *corresponding author: florin_sala@usab-m.ro
}

Bulletin UASVM Horticulture 75(1) / 2018

Print ISSN 1843-5262, Electronic ISSN 1843-536X

DOI:10.15835/buasvmcn-hort: 005117

\begin{abstract}
This study aimed at determining the leaf area in Liquidambar styraciflua $\mathrm{L}$. and at characterising the relationship between leaf area and leaf descriptors. The biological material was the species Liquidambar styraciflua L. We determined leaf area in 100 leaves (Figure 1) based on the size of median rib (L), leaf width at higher $\left(\mathrm{W}_{1}\right)$ and lower $\left(\mathrm{W}_{2}\right)$ lobe level, and on area constants $\left(\mathrm{K}_{\mathrm{A}}\right)$. The size of elements $\mathrm{L}, \mathrm{W}_{1}$ and $\mathrm{W}_{2}$ were found by measuring with a precision of $\pm 0.5 \mathrm{~mm}$. Area constants in the species Liquidambar styraciflua $\mathrm{L}$. were $\mathrm{K}_{\mathrm{A} 1}=$ 0.63 , determined depending on leaf width at upper lobe width $\left(\mathrm{W}_{1}\right)$, and $\mathrm{K}_{\mathrm{A2}}=0.81$ in relation to the width $\mathrm{W}_{2}$ of the lower lobes. Between the scanned leaf area (SLA) and measured leaf area (MLA) and leaf descriptors $\left(L, W_{1}\right.$ and $W_{2}$ ) we identified relations of interdependence statistically ensured: $r=0.960$ to $r=0.971$ for SLA; $r=0.951$ to $r=0.981$ for MLA $W_{1}$, and $r=0.933$ to $r=0.972$ for MLA $W_{2}$, respectively. Leaf descriptors $L, W_{1}$ and $\mathrm{W}_{2}$ had a differentiated contribution in determining SLA and MLA. SLA was influenced by leaf length (L) with higher statistic safety $\left(R^{2}=0.963, p<0.001, F=1277.2\right)$ than leaf width at upper lobe width W1 $\left(R^{2}=0.943\right.$; $\mathrm{p}<<0.001 ; \mathrm{F}=797.7)$ and leaf width at the extremities of the lower lobes $\mathrm{W}_{2}\left(\mathrm{R}^{2}=0.927, \mathrm{p}<<0.001, F=620.59\right)$.
\end{abstract}

Keywords: leaf area, LAC Model, Liquidambar, descriptors, leaves

\section{Introduction}

Leaf area is a morphological and physiological parameter in plants of interest for the reception of solar energy, the process of photosynthesis, relationship with the environment, ornamental issues, etc. Determining leaf area to characterise different plant species was done through different models, methods and techniques (destructive and non-destructive) (Jonckheere et al., 2004; Behera et al., 2010; Kirk et al, 2009; Fascella et al., 2009, 2013; Sala et al., 2015).

The Genus Liquidambar has four tree species: Liquidambar orientalis L., Liquidambar formosana Hance., Liquidambar styraciflua L., and Liquidambar acalycina L. (Adams et al., 2015; Lingbeck et al., 2015). The species Liquidambar styraciflua L. has various uses: ornamental, pharmaceutical, and medical (Lingbeck et al., 2015). Several studies have assessed the antioxidant and antimicrobial effects of some compounds and the quality of volatile oils (Sağdic et al., 2005; Carson et al., 2006; Wang et al., 2010; El-Readi et al., 2013).

The species has different types depending on leaf or other organs morphological parameters that have been studied and characterised in different studies (Gilman and Watson, 1993).

They have also carried out studies on productivity depending on leaf area and photosynthesis rate in Liquidambar styraciflua L. under different conditions of fertilisation, irrigation and pest control (Samuelson et al., 2001). 


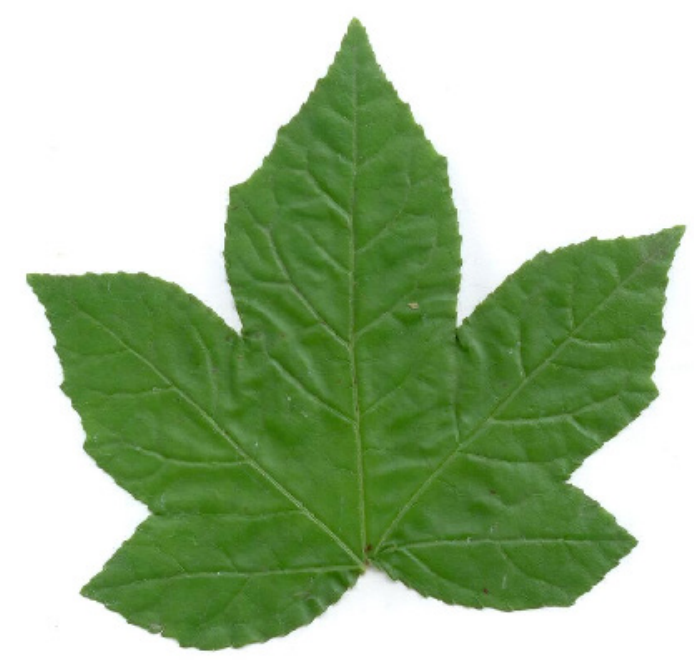

Figure 1. Leaf of Liquidambar styraciflua $\mathrm{L}$.

Table 1. Values of area constants $\mathrm{K}_{\mathrm{A} 1}$, MLA and safety parameters in Liquidambar styraciflua $\mathrm{L}$.

\begin{tabular}{|c|c|c|c|c|c|c|c|c|c|c|c|}
\hline \multicolumn{12}{|c|}{ Values of area constants $\left(\mathrm{KA}_{1}\right)$} \\
\hline SLA & & & & & & 46.93 & & & & & \\
\hline $\mathrm{KA}$ & 0.58 & 0.59 & 0.6 & 0.61 & 0.62 & 0.63 & 0.64 & 0.65 & 0.66 & 0.67 & 0.68 \\
\hline MLA & 43.02 & 43.76 & 44.51 & 45.25 & 45.99 & 46.73 & 47.47 & 48.21 & 48.96 & 49.70 & 50.44 \\
\hline $\mathrm{ME}$ & -3.91 & -3.17 & -2.43 & -1.68 & -0.94 & -0.20 & 0.54 & 1.28 & 2.03 & 2.77 & 3.51 \\
\hline RMSE & 5.4581 & 4.8111 & 4.218 & 3.7047 & 3.3086 & 3.0426 & 3.0753 & 3.2164 & 3.5669 & 4.0483 & 4.6199 \\
\hline
\end{tabular}

This study aimed at determining the leaf area in Liquidambar styraciflua L. and at characterising the relationship between leaf area and leaf descriptors.

\section{Materials and methods}

The biological material was the species Liquidambar styraciflua L. We determined leaf area in 100 leaves (Fig. 1) based on the size of median rib (L), leaf width at higher $\left(\mathrm{W}_{1}\right)$ and lower $\left(\mathrm{W}_{2}\right)$ lobe level, and on area constants (KA). Results were compared with leaf area determined through scanning (SLA) as reference, based on the model proposed by Sala et al. (2015). The size of the elements L, W1 and W2 was obtained by measurements with a precision of $\pm 0.5 \mathrm{~mm}$.

Experimental data were analysed and statistically processed through correlation analysis and regression, and the interdependence between descriptors and MLA and SLA thus obtained was described by $2^{\text {nd }}$ degree polynomial functions. The precision MLA assessment element was the mean of minimum errors (MME) and statistic safety parameters were represented by the correlation coefficients $\mathrm{R}^{2}, \mathrm{p}, \mathrm{F}$ and RMSE.

\section{Results and discussion}

Based on individual values of the median vein length (L) and of upper lobe width $\left(W_{1}\right)$ and lower lobe width $\left(\mathrm{W}_{2}\right)$, we obtained the mean values of these elements. Area constants for the species Liquidambar styraciflua $\mathrm{L}$. were $\mathrm{K}_{\mathrm{A} 1}=0.63$ determined depending on upper lobes width $\left(\mathrm{W}_{1}\right)$ and $\mathrm{K}_{\mathrm{A} 2}=0.81$ and on lower lobe width $\mathrm{W}_{2}$. Based on leaf size $\left(\mathrm{L}, \mathrm{W}_{1}\right.$ and $\mathrm{W}_{2}$ ) and on area constants $\mathrm{K}_{\mathrm{A}^{\prime}}$ determined based on the model proposed by Sala et al. (2015), we calculated leaf area with high precision. Compared to the scanned leaf area, themean of minimum error mean of measured leaf area was $-0.20 \mathrm{~cm}^{2}$ (RMSE $=3.0426$ ) when calculating based on upper lobe width $\left(\mathrm{W}_{1}\right)$ and $-0.06 \mathrm{~cm}^{2}(\mathrm{RMSE}=4.3826)$ when 
Table 2. Values of area constants $\mathrm{K}_{\mathrm{A} 2}$, MLA and safety parameters in Liquidambar styraciflua $\mathrm{L}$.

\begin{tabular}{|c|c|c|c|c|c|c|c|c|c|c|c|}
\hline & & & & & Jalues of a & area cons & $\operatorname{tants}\left(\mathrm{K}_{\mathrm{A}}\right.$ & & & & \\
\hline SLA & & & & & & 46.93 & & & & & \\
\hline KA & 0.76 & 0.77 & 0.78 & 0.79 & 0.8 & 0.81 & 0.82 & 0.83 & 0.84 & 0.85 & 0.86 \\
\hline MLA & 43.97 & 44.55 & 45.13 & 45.71 & 46.29 & 46.87 & 47.45 & 48.02 & 48.60 & 49.18 & 49.76 \\
\hline MME & -2.96 & -2.38 & -1.80 & -1.22 & -0.64 & -0.06 & 0.52 & 1.09 & 1.67 & 2.25 & 2.83 \\
\hline RMSE & 5.5359 & 4.9886 & 4.7158 & 4.5177 & 4.4045 & 4.3826 & 4.4534 & 4.6127 & 4.8517 & 5.1594 & 5.5243 \\
\hline
\end{tabular}

Table 3. ANOVA test for single factor

\begin{tabular}{ccccccc}
\hline Source of variation & $S S$ & $d f$ & $M S$ & $F$ & P-value & F.crit \\
\hline Between groups & 226061 & 5 & 45212.2 & 207.9989 & $5.9 \mathrm{E}-128$ & 4.16402 \\
\hline Within groups & 129116.3 & 594 & 217.3675 & & & \\
\hline Total & 355177.3 & 599 & & & & \\
\hline Alpha $=0.001$ & & & & & \\
\hline
\end{tabular}

calculating based on leaf width at lower lobes $\left(\mathrm{W}_{2}\right)$. Based on the leaf dimensions ( $\mathrm{L}$ and $\mathrm{w}$ ) and the surface constants $\mathrm{K}_{\mathrm{A} 1}$ and $\mathrm{K}_{\mathrm{A} 2}$, the foliar surface was determined by the relation (1).

Data are shown in Tables 1 and 2 below.

$\mathrm{MLA}=\mathrm{L} \times \mathrm{W} \times \mathrm{K}_{\mathrm{A}} \quad$ (1)

Where: MLA - Leasured Leaf Area; L - leaf length; $\mathrm{w}$ - leaf width; $\mathrm{K}_{\mathrm{A}}$ - constants of leaf area, $\mathrm{K}_{\mathrm{A} 1}$ and $\mathrm{K}_{\mathrm{A} 2}$.

We identified statistically ensured interdependence relations between scanned leaf area (SLA) and measured leaf area (MLA) and leaf descriptors $\left(\mathrm{L}, \mathrm{W}_{1}\right.$ and $\mathrm{W}_{2}$ ): $\mathrm{r}=0.960$ to $\mathrm{r}=0.971$ for SLA; $r=0.951$ to $r=0.981$ for MLA W1, and $r=$ 0.933 to $r=0.972$ for MLA $W_{2}$, respectively.

We identified interdependence relations between leaf descriptors and scanned leaf area (SLA) and measured leaf area (MLA), respectively.

The interdependence between SLA and individual leaf descriptors ( $\mathrm{L}, \mathrm{W}_{1}$ and $\mathrm{W}_{2}$ ) was described by $2^{\text {nd }}$ degree polynomial functions (relations 2, 3 and 4), with statistic ensurance.

$$
\begin{aligned}
& \mathrm{SLA}_{\mathrm{L}}=0.8669 \mathrm{x}^{2}-0.8305 \mathrm{x}+1.515 \\
& \mathrm{SLA}_{\mathrm{W} 1}=0.405 \mathrm{x}^{2}+1.851 \mathrm{x}-8 \\
& \mathrm{SLA}_{\mathrm{W} 2}=0.297 \mathrm{x}^{2}+5.038 \mathrm{x}-6.279
\end{aligned}
$$

Thus, leaf descriptors $\mathrm{L}, \mathrm{W}_{1}$ and $\mathrm{W}_{2}$ had a different contribution to the calculus of SLA and MLA. Scanned leaf area (SLA) was influenced by leaf length (L) with higher statistic ensurance
$\left(\mathrm{R}^{2}=0.963, \mathrm{p}<<0.001, \mathrm{~F}=1277.2\right)$ than upper lobe width $\mathrm{W}_{1}\left(\mathrm{R}^{2}=0.943 ; \mathrm{p}<<0.001 ; \mathrm{F}=797.7\right)$ and leaf width at the extremity of lower lobes $\mathrm{W}_{2}$ $\left(R^{2}=0.927, p<<0.001, F=620.59\right)$. Independence relations are shown in Figures 2-4, where: SLA $_{\mathrm{L}}-$ leaf area based on leaf length, $\mathrm{SLA}_{\mathrm{w} 1}$ - leaf area based on upper lobe width, $\mathrm{SLA}_{\mathrm{w} 2}$ - leaf area based on lower lobe width; $\mathrm{x}$ - parameter depending on which we determined leaf area.

Measured leaf area (MLA) depending on upper lobe width (W1), was differently influenced by leaf length (L) under statistic safety conditions R2 = $0.971, \mathrm{p}<0.001, \mathrm{~F}=1598.7$ (relation 5) and by leaf width (W1) under statistic safety conditions $\mathrm{R} 2=0.974 ; \mathrm{p}<<0.001 ; \mathrm{F}=1789.7$ (relation 6). The distribution of interdependence relations between MLA $_{\mathrm{w}}$ and leaf length (L) and $\mathrm{W}_{1}$, respectively, are shown in Figures 5 and 6.

$$
\begin{aligned}
& \operatorname{MLA}_{\mathrm{w} 1}=0.69 \mathrm{x}^{2}+1.167 \mathrm{x}-3.183 \\
& \mathrm{MLA}_{\mathrm{w} 2}=0.3834 \mathrm{x}^{2}+1.888 \mathrm{x}-6.549
\end{aligned}
$$

Measuredleaf area(MLA) depending onlower lobe width $\left(\mathrm{W}_{2}\right)$ was differently influenced by leaf length (L) under statistic safety conditions $\mathrm{R}^{2}=$ $0.969, \mathrm{p}<0.001, \mathrm{~F}=1526.2$ (relation 7) and by leaf width $\left(\mathrm{W}_{2}\right)$ under statistic safety conditions $\mathrm{R}^{2}=0.984 ; \mathrm{p}<<0.001 ; \mathrm{F}=2956.4$ (relation 8). The interdependence relations between MLA $_{w_{2}}$ and leaf length $(\mathrm{L})$ and $\mathrm{W}_{2}$, respectively, are shown in Figures 7 and 8. 


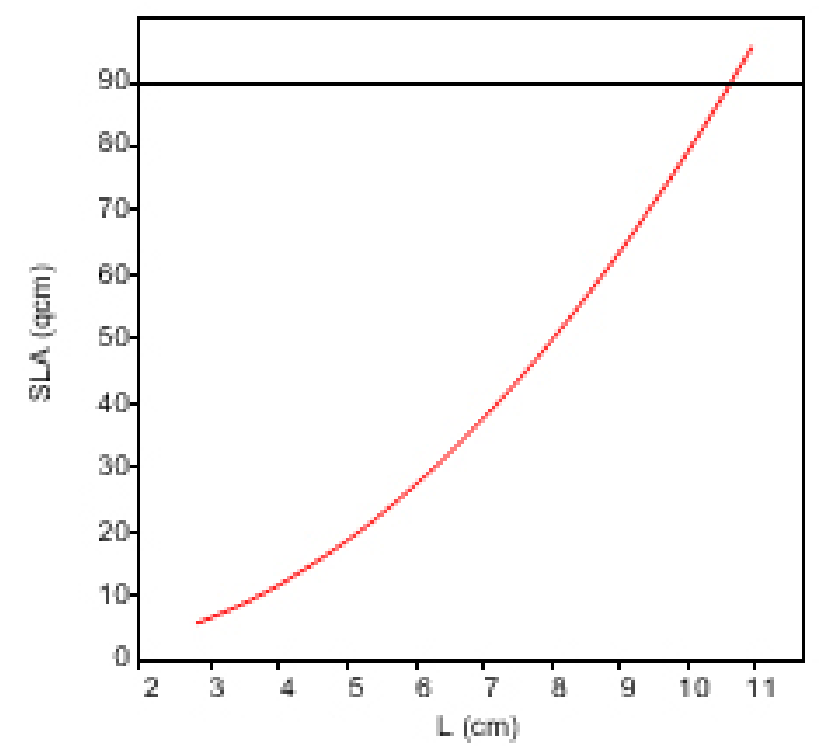

Figure 2. Distribution of the interdependence relation between SLA and L

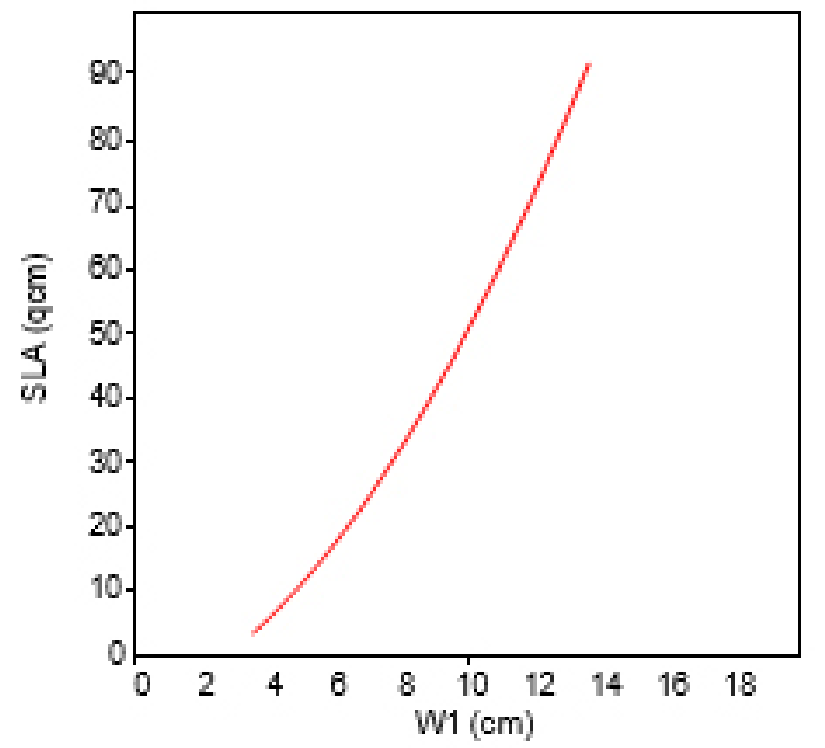

Figure 3. Distribution of the interdependence relation between SLA and $\mathrm{W}_{1}$

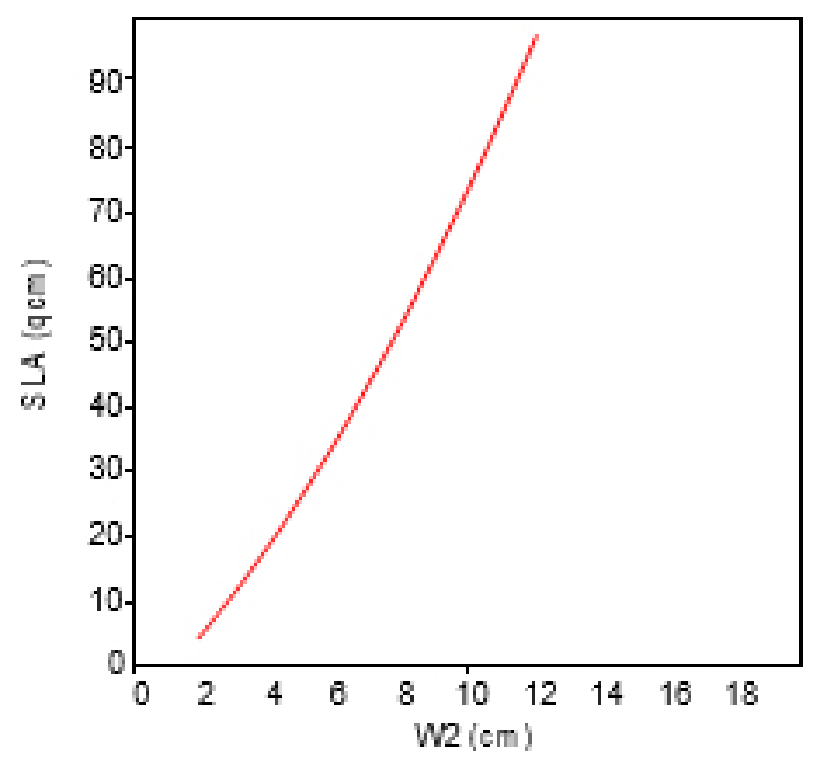

Figure 4. Distribution of the interdependence relation between SLA and $\mathrm{W}_{2}$

$\mathrm{MLA}_{\mathrm{W} 2}=0.9988 \mathrm{x}^{2}-1.772 \mathrm{x}+0.6835$

$\mathrm{MLA}_{\mathrm{w} 2}=0.4888 \mathrm{x}^{2}+3.355 \mathrm{x}-5.055$

Determining leaf area based on leaf descriptors is non-destructive, quick, enough accurate and low cost. To determine leaf area, we use direct relations between leaf length and correction coefficients or area constants (Sala et al., 2015) or different software applications and models (Kumar et al., 2017). We can also use linear or polynomial regression models to calculate leaf area based only on independent descriptors of the leaf between which there are not such relations (Blanco and Folegatti, 2003; Mokhtarpour et al., 2010; Rouphael et al., 2010).

The study of leaf area was carried out on different horticultural species depending on nutrition (Jivan and Sala, 2014) to characterise tree species (Sala et al., 2017).

In Liquidambar, leaf specificity made possible determining leaf area based on $\mathrm{L}, \mathrm{W}_{1}$ and $\mathrm{W}_{2}$. Leaf area in Liquidambar was studied by Kuers and Steinbeck (1998) depending on $\mathrm{N}$ fertilisation 


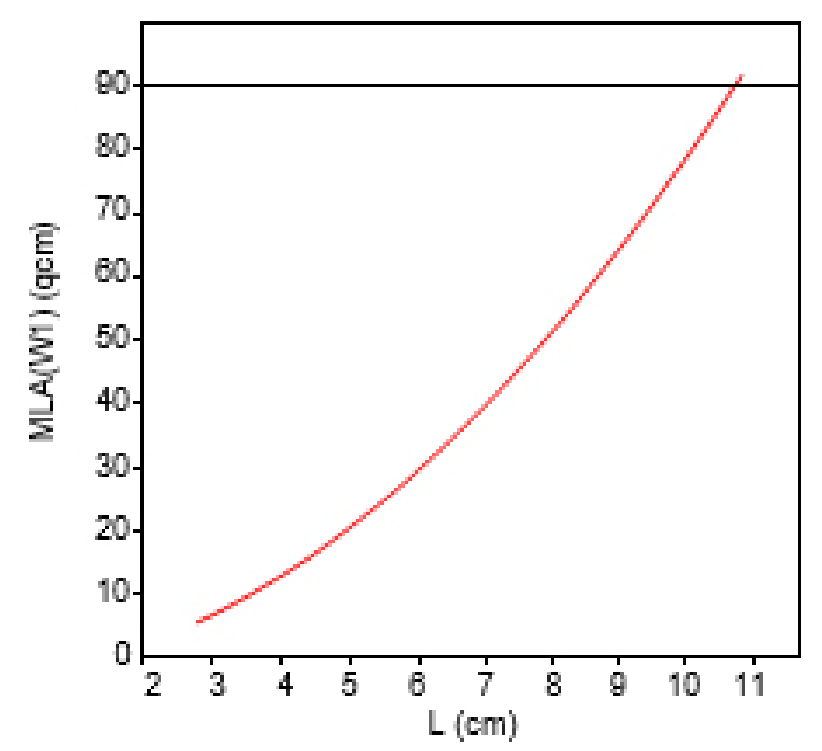

Figure 5. Distribution of the interdependence between $\mathrm{MLA}_{\mathrm{W} 1}$ and L

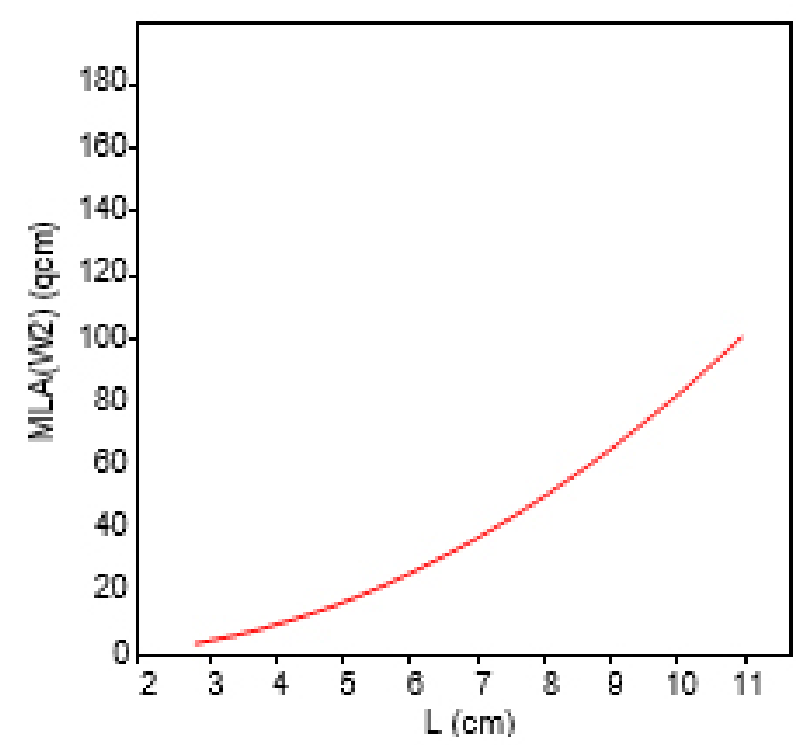

Figure 7. Distribution of the interdependence relation between $\mathrm{MLA}_{\mathrm{w} 2}$ and $\mathrm{L}$

and on vertical and temporal leaf distribution. They identified an increase of the leaf area and of the total leaf weight in trees fertilised with $\mathrm{N}$ due rather to an increase of leaf size than to an increase of leaf number and of specific leaf weight.

\section{Conclusions}

Leaf geometry in Liquidambar styraciflua L. facilitated the measurement of leaf area based on

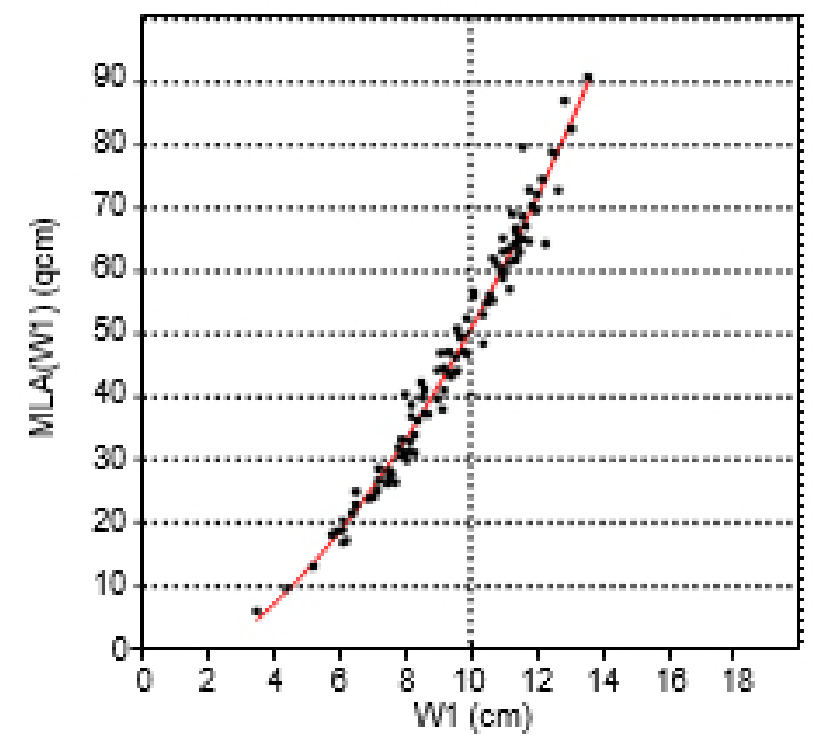

Figure 6. Distribution of the interdependence between $\mathrm{MLA}_{\mathrm{W} 1}$ and $\mathrm{W}_{1}$

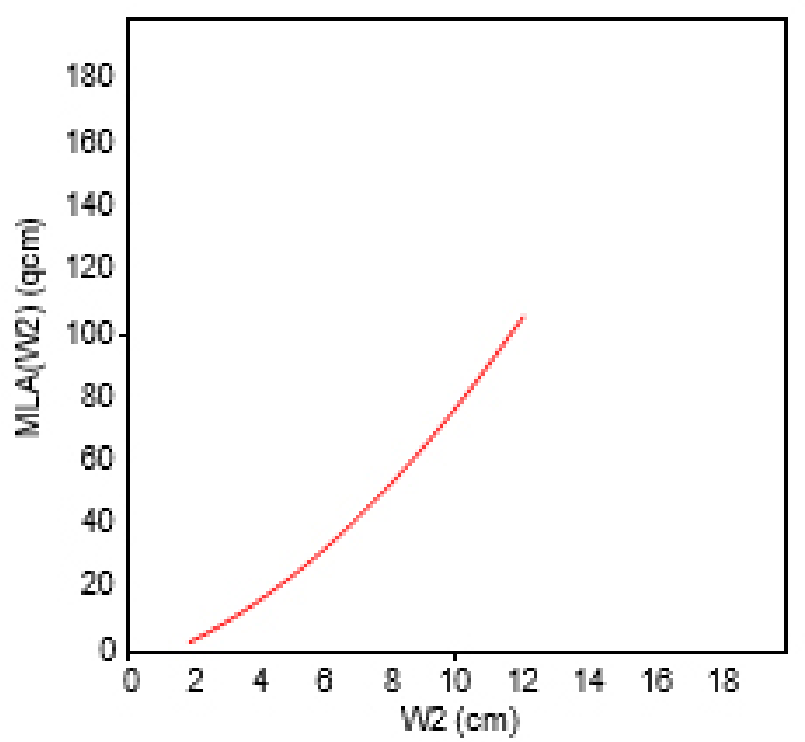

Figure 8. Distribution of the interdependence relation between $\mathrm{MLA}_{\mathrm{W} 2}$ and $\mathrm{W}_{2}$

the length of the median vein and on the upper and lower lobe width $\left(\mathrm{W}_{1}\right)$ and $\left(\mathrm{W}_{2}\right)$, respectively.

Leaf area calculated based on lower lobe width was more accurate than that calculated based on lower lobe width compared to scanned leaf area (SLA).

We identified interdependence relations between the values of scanned leaf area and of 
measured leaf area, which confirms the accuracy of the measurement based on leaf descriptors.

\section{References}

1. Adams JP, Lingbeck JM, Crandall PG, Martin EM, O’Bryan CA (2015). Sweetgum: a new look. iForest 8: 719-727.

2. Behera SK, Srivastava P, Pathre UV, Tuli (2010). An indirect method of estimating leaf area index in Jatropha curcas $\mathrm{L}$. using LAI-2000 Plant Canopy Analyzer. Agricultural and Forest Meteorology, 150: 307-311.

3. Blanco FF, Folegatti, MV (2003). A new method for estimating the leaf area index of cucumber and tomato plants. Horticultura Brasileira, 21(4): 666-669.

4. Carson CF, Hammer KA, Riley TV (2006). Melaleuca alternifolia (Tea Tree) Oil: A review of antimicrobial and other medicinal properties. Clin Microbiol Rev, 19: 50-62.

5. El-Readi MZ, Eid HH, Ashour ML, Eid SY, Labib RM, Sporer F, Wink M (2013). Variations of the chemical composition and bioactivity of essential oils from leaves and stems of Liquidambar styraciflua (Altingiaceae). J Pharm Pharmacol, 65: 1653-1663.

6. Fascella G, Maggiore P, Zizzo GV, Colla G, Rouphael Y (2009). A simple and lowcost method for leaf area measurement in Euphorbia x lomi Thai hybrids". Advances in Horticultural Science, 23(1): 57-60.

7. Fascella G, Darwich S, Rouphael Y (2013). Validation of a leaf area prediction model proposed for rose. Chilean J. Agric. Res, 73(1): 73-76.

8. Gilman EF, Watson DG (1993). Liquidambar styraciflua 'Rotundiloba' 'Rotundiloba' Sweetgum. Fact Sheet ST-362.

9. Jivan C, Sala F (2014). Relationship between tree nutritional status and apple quality. Horticultural Science, 41(1): 1-9.

10. Jonckheere I, Fleck S, Nackaerts K, Muys B, Coppin P, Weiss M, Baret F (2004). Review of methods for in situ leaf area index determination: Part I. Theories, sensors and hemispherical photography. Agricultural and Forest Metrology, 121: 19-35.

11. Kirk K, Andersen HJ, Thomsen AG, Jřrgensen JR, Jřrgensen RN (2009). Estimation of leaf area index in cereal crops using red-green images, Biosystems Engineering, 104: 308-317.

12. Kumar MK, Kumar RS, Sankar V, Sakthivel T, Karunakaren G, Tripathi PC (2017). Non-destructive estimation of leaf area of durian (Durio zibethinus) - An artificial neural network approach. Scientia Horticulturae, 219: 319-325.

13. Lingbeck JM, O’Bryan CA, Martin EM, Adams JP, Crandall PG, Sweetgum: An ancient source of beneficial compounds with modern benefits. Pharmacogn Rev, 9(17): 1-11.

14. Kuers K, Steinbeck K (1998). Leaf area dynamics in Liquidambar styraciflua saplings: responses to nitrogen fertilization. Canadian Journal of Forest Research, 1998, 28(11): 1660-1670.

15. Mokhtarpour H, Teh CBS, Saleh G, Selamat AB, Asadi ME, Kamkar B (2010). Non-destructive estimation of maize leaf area, fresh weight, and dry weight using leaf length and leaf width, Communications in Biometry and Crop Science, 5(1): 19-26.

16. Rouphael Y, Mouneimne AH, Ismail A, Mendoza-de Gyves E, Rivera CM, Colla G (2010). Modeling individual leaf area of rose (Rosa hybrida L.) based on leaf length and width measurement. Photosynthetica, 48(1): 9-15.

17. Sağdic O, Ozkan G, Ozcan M, Ozcelik S (2005). A study on inhibitory effects of Sigla Tree (Liquidambar orientalis Mill. var orientalis) storax against several bacteria. Phytother Res, 19:549-51.

18. Sala F, Arsene GG, Iordănescu O, Boldea M (2015). Leaf area constant model in optimizing foliar area measurement in plants: A case study in apple tree. Scientia Horticulturae, 193: 218-224.

19. Sala F, Iordănescu O, Dobrei A (2017). Fractal analysis as a tool for pomology studies: Case study in apple. Agrolife Scientific Journal, 6(1): 224-233.

20. Samuelson L, Stokes T, Cooksey T, McLemore P (2001). Production efficiency of loblolly pine and sweetgum in response to four years of intensive management. Tree Physiology, 21: 369-376.

21. Wang K, Pan Y, Wang H, Zhang Y, Lei Q Zhu Z, Li H, Lianh M (2010). Antioxidant activities of Liquidambar formosana Hance leaf extracts. Med Chem Res, 19:166-76. 